\title{
Feasibility of Using Microalgae for Biocement Production through Biocementation
}

\author{
Dessy Ariyanti*, Noer Abyor Handayani and Hadiyanto \\ Department of Chemical Engineering, Faculty of Engineering, Diponegoro University, Prof Soedarto, SH Kampus Tembalang, Semarang, Indonesia
}

\begin{abstract}
The invention of microorganism's involvement in carbonate precipitation, has lead the exploration of this process in the field of construction engineering. Biocement is a product innovation from developing bioprocess technology called biocementation. Biocement refers to $\mathrm{CaCO}_{3}$ deposit that formed due to microorganism activity in the system rich of calcium ion. The primary role of microorganism in carbonate precipitation is mainly due to their ability to create an alkaline environment (high pH and DIC increase) through their various physiological activities. Three main groups of microorganism that can induce the carbonate precipitation: (i) photosynthetic microorganism such as cyanobacteria and microalgae; (ii) sulphate reducing bacteria; and (iii) some species of microorganism involved in nitrogen cycle. Microalgae are photosynthetic microorganism and utilize urea using urease or urea amidolyase enzyme, based on that it is possible to use microalgae as media to produce biocement through biocementation. This paper overviews biocement in general, biocementation, type of microorganism and their pathways in inducing carbonate precipitation and the prospect of microalgae to be used in biocement production.
\end{abstract}

Keywords: Biocement; Biocementation; Microalgae; $\mathrm{CaCO}_{3}$ precipitation

\section{Introduction}

Construction engineering consumes a large amount of materials from non-renewable resources, which most of the materials contribute $\mathrm{CO}_{2}$ emission to the air at their production or application stage. Technology development related to the construction material and their production is necessary, in order to maintain the sustainability and to reduce the production of $\mathrm{CO}_{2}$ emission. The evidence of microorganism involvement in carbonate precipitation, has lead the development of bioprocess technology in the field of construction material $[1,2]$.

The precipitation of calcium carbonate $\left(\mathrm{CaCO}_{3}\right)$ may be performed due to microorganism activity and it produces massive limestone or small crystal forms [3]. These deposit of calcium carbonate known as biocement or microbial induced carbonate precipitation (MICP) [3,4]. Biocement has many advantages compared to an ordinary cement, such as: the production process is slightly different with sandstone production, biocement need a much shorter time; it is suitable for in-situ process; raw material of biocement are produced at low temperature, more efficient compared to an ordinary cement which used temperature up to $1500^{\circ} \mathrm{C}$ in production process; biocement can be used as ecoconstruction material since it consume less energy and less $\mathrm{CO}_{2}$ emission in the production process rather than other ordinary cement $[3,5]$.

Recently, research and study of biocement production through biocementation still focused to the nitrogen cycle mechanism using urease enzyme producing bacteria [3-7]. While research using microalgae as media for biocementation still lack in literature, in fact microalgae have a great potency for the objective of biocementation. Overview of biocement, biocementation, type of microorganism, mechanism type and feasibility of microalgae as media for biocement production will briefly described throughout this paper.

\section{Microbial Induced Carbonate Precipitation (MCIP)}

Calcium carbonate $\left(\mathrm{CaCO}_{3}\right)$ precipitation is a common phenomenon found in nature such as marine water, freshwater, and soils $[1,6,8]$. This precipitation is governed by four key factors: (i) the calcium $\left(\mathrm{Ca}^{2+}\right)$ concentration, (ii) the concentration of dissolved inorganic carbon
(DIC), (iii) the $\mathrm{pH}\left(\mathrm{pK} 2(\mathrm{CO})=10.3\right.$ at $\left.25^{\circ} \mathrm{C}\right)$ and (iv) the availability of nucleation sites $[1,9]$. Numerous species of microorganism have been detected previously and assumed to be associated with natural carbonate precipitates from diverse environments. The primary role of microorganism in carbonate precipitation is mainly due to their ability to create an alkaline environment (high $\mathrm{pH}$ and [DIC] increase) through their various physiological activities $[1,6]$

There are three main groups of microorganism that can induce the carbonate precipitation: (i) photosynthetic microorganism such as cyanobacteria and microalgae; (ii) sulphate reducing bacteria; and (iii) some species of microorganism involved in nitrogen cycle $[1,6,7]$. The most common MCIP phenomena appeared in aquatic environments is caused by photosynthetic microorganisms $[7,10]$. Photosynthetic microorganisms use $\mathrm{CO}_{2}$ in their metabolic process (equation 1) which is in equilibrium with $\mathrm{HCO}_{3}$ - and $\mathrm{CO}_{3}{ }^{2-}$ as described in equation 2. Carbon dioxide consumed by photosynthetic microorganisms shift the equilibrium and resulting the increment of $\mathrm{pH}$ (equation 3) [7]. When this reaction occurs in the present of calcium ion in the system, calcium carbonate is produced as described at chemical reaction in equation 4 [6].

$$
\begin{aligned}
& \mathrm{CO}_{2}+\mathrm{H}_{2} \mathrm{O} \rightarrow\left(\mathrm{CH}_{2} \mathrm{O}\right)+\mathrm{O}_{2} \\
& 2 \mathrm{HCO}_{3}-\leftrightarrow \mathrm{CO}_{2}+\mathrm{CO}_{3}{ }^{2}-+\mathrm{H}_{2} \mathrm{O} \\
& \mathrm{CO}_{3}{ }^{2}+\mathrm{H}_{2} \mathrm{O} \leftrightarrow \mathrm{HCO}_{3}-+\mathrm{OH}- \\
& \mathrm{Ca}^{2+}+\mathrm{HCO}_{3}-+\mathrm{OH}-\leftrightarrow \mathrm{CaCO}_{3}+2 \mathrm{H}_{2} \mathrm{O}
\end{aligned}
$$

*Corresponding author: Dessy Ariyanti, Department of Chemical Engineering Faculty of Engineering, Diponegoro University, Prof Soedarto, SH Kampus Tembalang, Semarang, Indonesia, Tel: +62-24-7460058; Fax: +62-24-76480675; E-mail: dessy@undip.ac.id

Received December 24, 2011; Accepted January 19, 2012; Published January 22, 2012

Citation: Ariyanti D, Handayani NA, Hadiyanto (2012) Feasibility of Using Microalgae for Biocement Production through Biocementation. J Bioprocess Biotechniq 2:111 doi: 10.4172/2155-9821.1000111

Copyright: ( 2012 Ariyanti D, et al. This is an open-access article distributed unde the terms of the Creative Commons Attribution License, which permits unrestricted use, distribution, and reproduction in any medium, provided the original author and source are credited. 
The precipitation of calcite $\left(\mathrm{CaCO}_{3}\right)$ can also be induced by heterotrophic organism. This microorganism produces carbonate or bicarbonate and modified the system so that the carbonate precipitation may occur [1]. Abiotic dissolution of gypsum $\left(\mathrm{CaSO}_{4} \cdot \mathrm{H}_{2} \mathrm{O}\right)$ (equation 5) causes system rich of sulphate and calcium ion. In the presence of organic matter and the absence of oxygen, sulphate reducing bacteria (SRB) can reduce sulphate to $\mathrm{H}_{2} \mathrm{~S}$ and $\mathrm{HCO}_{3}$ - as described in equation $6[1,7]$. When the $\mathrm{H}_{2} \mathrm{~S}$ degasses from the environment, $\mathrm{pH}$ of system will increase and the precipitation of calcium carbonate will occur [1].

$$
\begin{aligned}
& \mathrm{CaSO}_{4} \cdot \mathrm{H}_{2} \mathrm{O} \rightarrow \mathrm{Ca}^{2+}+\mathrm{SO}_{4}{ }^{2}-+2 \mathrm{H}_{2} \mathrm{O} \\
& 2\left(\mathrm{CH}_{2} \mathrm{O}\right)+\mathrm{SO}_{4}{ }^{2-} \rightarrow \mathrm{HS}^{-}+\mathrm{HCO}_{3}+\mathrm{CO}_{2}+\mathrm{H}_{2} \mathrm{O}
\end{aligned}
$$

Currently, urease enzyme activity in most of microorganism metabolism process has been used as a tool to induce the precipitation of calcium carbonate $[11,12]$. The hydrolysis of urea by urease enzyme in heterotrophic microorganism will produce carbonate ion and ammonium. This mechanism will result system with higher $\mathrm{pH}$ and rich of carbonate ion [12]. One mole of urea hydrolysed intracellularly to one mole ammonia and one mole carbamate (equation 7), which spontaneously hydrolysed to one mole ammonia and one mole carbonic acid (equation 8). Ammonia and carbamate subsequently equilibrate in water to form bicarbonate and 2 moles of ammonium and hydroxide ions as described in equation 9 and 10 [2].

$$
\begin{aligned}
& \mathrm{CO}\left(\mathrm{NH}_{2}\right)_{2}+\mathrm{H}_{2} \mathrm{O} \rightarrow \mathrm{H}_{2} \mathrm{COOH}+\mathrm{NH}_{3} \\
& \mathrm{NH}_{2} \mathrm{COOH}+\mathrm{H}_{2} \mathrm{O} \rightarrow \mathrm{NH}_{3}+\mathrm{H}_{2} \mathrm{CO}_{3} \\
& 2 \mathrm{NH}_{3}+2 \mathrm{H}_{2} \mathrm{O} \rightarrow 2 \mathrm{NH}_{4}^{+}+2 \mathrm{OH}^{-} \\
& 2 \mathrm{OH}-+\mathrm{H}_{2} \mathrm{CO}_{3} \rightarrow \mathrm{CO}_{3}{ }^{2-}+2 \mathrm{H}_{2} \mathrm{O}
\end{aligned}
$$

Total reaction:

$$
\mathrm{CO}\left(\mathrm{NH}_{2}\right)_{2}+2 \mathrm{H}_{2} \mathrm{O} \rightarrow 2 \mathrm{NH}_{4}^{+}+\mathrm{CO}_{3}^{2}
$$

The presence of calcium ion in the system will lead to the calcium carbonate precipitation once a certain level of supersaturation is reached. The calcium carbonate precipitation mechanism induced by urease enzyme activity illustrated in figure 1.

Calcium ions in the solution are attracted to microorganism cell wall due to the negative charge of the latter. After the addition of urea to the system, microorganism convert urea to dissolved inorganic carbon (DIC) and ammonium (AMM) and released it to the environment (A). The presence of calcium ion cause the supersaturation condition and precipitation of calcium carbonate in microorganism cell wall (B). After a while, the whole cell becomes encapsulated by calcium carbonate precipitate (C). As whole cell encapsulated, nutrient transfer becomes limited and resulting in cell death. Image (D) shows the imprints of microorganism cell involved in carbonate precipitation [6].

\section{Biocementation}

Biocementation is a process to produce binding material (biocement) based on microbial induced carbonate precipitation (MICP) mechanism. This process can be applied in many fields such as construction, petroleum, erosion control, and environment. Application in construction field include wall and building coating method, soil strengthening and stabilizing, and sand stabilizing in earthquake prone zone [2].

In application, the precipitation of calcium carbonate (biocement) is combined with other supporting material such as sand. The patented method of producing biocement can be seen in figure $2[7,4]$.

Biocementation illustrated in figure 2 uses heterotroph bacteria Bacillus pasteurii with urea hydrolysis mechanism. The cementation process occurs in pipe columns filled with commercial sand contained silica. Urea/calcium solution and bacteria solution were mixed immediately and put in the pressurized vessel to be injected to the sand core in pipe column for several time until the sand core fully saturated. Biocementation takes about 24 hours to complete the reaction, after that the biocement were dried in temperature of $60^{\circ} \mathrm{C}$ [7].

Biocementation were also developed in the process of biological mortar production, crack in concrete remediation and production of bacterial concrete [2,9]. Table 1 shows overview of various construction materials made from biocementation.

In general, mortar refers to "ready to use" binder material contained a binder, and sand or aggregate. Biological mortar consists of three main components such as limestone powder, nutrient and bacterial paste [2]. Biocementation applied in concrete rift remediation and the production of bacterial concrete has been investigated (Santhosh et al. [13]). Specimen of crack in concrete filled with biocement shows the significant increment of strength and stiffness value compared with specimen without biocement [13].

Theoretically, calcium carbonate precipitation occur in nature following several process such as: (i) abiotic chemical precipitation from saturated solution due to evaporation, temperature increase and/or pressure decrease; (ii) production of external and internal skeleton by eukaryotes; (iii) $\mathrm{CO}_{2}$ pressure derivation under effect of autotrophic processes (photosynthesis, methanogenesis); (iv) fungal mediation;
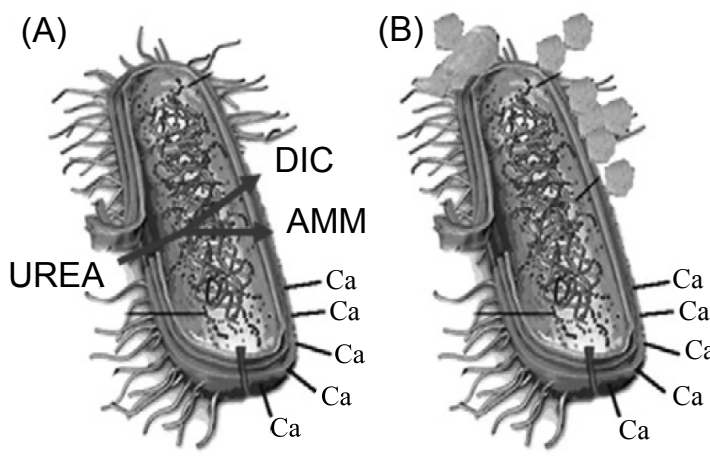

(C)

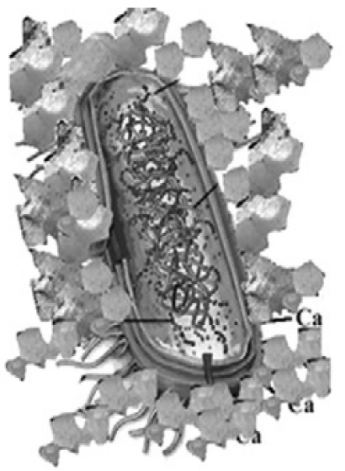

(D)

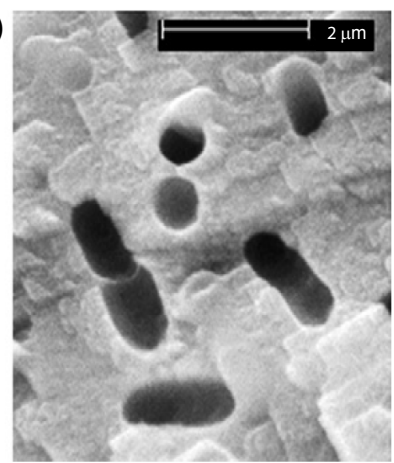

Figure 1: Illustration of calcium carbonate precipitation mechanism induced by urease enzyme activity in microorganism [6] 


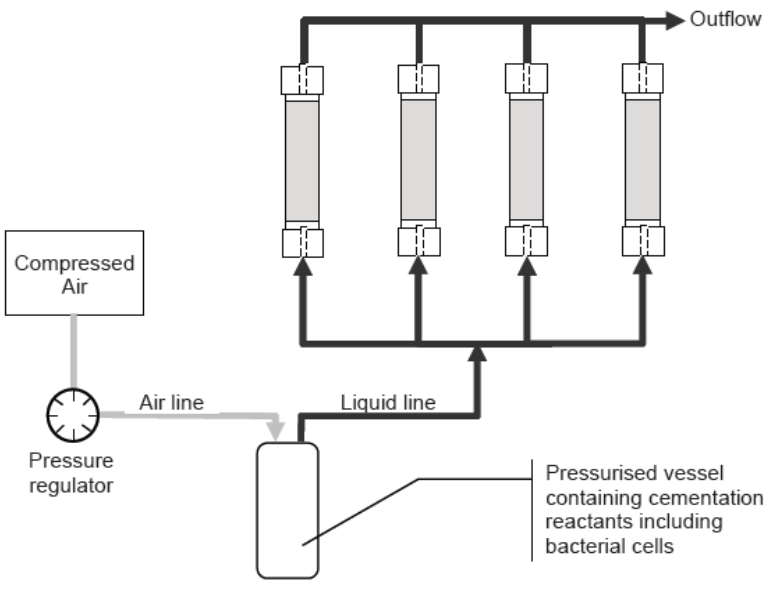

Figure 2: Injection method of cementation liquid (contain calcium/urea solution and bacterial cell) in biocementation $[4,7]$.

\begin{tabular}{|c|c|c|c|c|}
\hline Application & Microorganism & Metabolism & Solution & Reference \\
\hline $\begin{array}{l}\text { Biological } \\
\text { mortar }\end{array}$ & Bacillus cereus & $\begin{array}{l}\text { oxidative } \\
\text { deamination of } \\
\text { amino acids }\end{array}$ & $\begin{array}{l}\text { Growth media } \\
\text { (peptone, extract } \\
\text { yeast, } \mathrm{KNO}_{3}, \mathrm{NaCl} \text { ) } \\
+\mathrm{CaCl}{ }_{2} \cdot 2 \mathrm{H}_{2} \mathrm{O}, \text { Acti- } \\
\text { cal, Natamycine }\end{array}$ & [2] \\
\hline \multirow[t]{2}{*}{$\begin{array}{l}\text { Crack in } \\
\text { concrete } \\
\text { remediation }\end{array}$} & Bacillus pasteurii & $\begin{array}{l}\text { Hydrolysis of } \\
\text { urea }\end{array}$ & $\begin{array}{l}\text { Nutrient broth, urea, } \\
\mathrm{CaCl}_{2} \cdot 2 \mathrm{H}_{2} \mathrm{O}, \mathrm{NH}_{4} \mathrm{Cl} \text {, } \\
\mathrm{NaHCO}_{3}\end{array}$ & [13] \\
\hline & $\begin{array}{l}\text { Bacillus sphaeri- } \\
\text { cus }\end{array}$ & $\begin{array}{l}\text { Hydrolysis of } \\
\text { urea }\end{array}$ & $\begin{array}{l}\text { Extract yeast, urea, } \\
\mathrm{CaCl}_{2} \cdot 2 \mathrm{H}_{2} \mathrm{O}\end{array}$ & [9] \\
\hline $\begin{array}{l}\text { Bacterial } \\
\text { concrete }\end{array}$ & Bacillus pasteurii & $\begin{array}{l}\text { Hydrolysis of } \\
\text { urea }\end{array}$ & $\begin{array}{l}\text { Nutrient broth, urea, } \\
\mathrm{CaCl}_{2} \cdot 2 \mathrm{H}_{2} \mathrm{O}, \mathrm{NH}_{4} \mathrm{Cl}, \\
\mathrm{NaHCO}_{3}\end{array}$ & [13] \\
\hline
\end{tabular}

Table 1: Overview of various construction materials made from biocementation.

(v) heterotrophic bacterial mediation [1]. Most of the mentioned processes above are mediated by microorganism. Both photosynthetic and heterotrophic microorganisms have natural ability to induce the precipitation of calcium carbonate. There are large amount of microorganism in many type of species spreads throughout the world. Table 2 shows several species which is already investigated as media in calcium carbonate precipitation [6].

In biocementation, microorganism that used as media should meet the specific requirement, since the process create a high $\mathrm{pH}$ in the environment and involving high concentration of calcium ion. For example, in biocementation based on urea hydrolysis, the process will produce high concentration of ammonium and not all type of microorganism can survive in such condition. Based on that, the selected of microorganism should meet the criteria such as: (i) have a high urease enzyme activity; (ii) ammonium and calcium ion tolerable; (iii) not pathogenic [7].

\section{Feasibility of Using Microalgae in Biocementation}

Microalgae are a promising media to be used in biocementation, due to its photosynthetic metabolism. Algae's species like Spirulina, Arthrospira plantensis (Cyanophyta), Chlorella vulgaris (Chlorophyta), Dunaliella salina, Haematococcus pluvialis, Muriellopsis sp., Porphyridium cruentum (Rhodophyta) basically are autotrophic microorganisms that live through photosynthetic process [14-16].
Experiment of nine green algae, a diatom and three cyanobacteria were shown to precipitate $\mathrm{CaCO}_{3}$ in batch culture, where grown in the light in a hard water medium containing $68 \mathrm{mg} \mathrm{L}^{-1}$ soluble calcium. The composition of the medium was based on that found in natural marine hard water where precipitation of $\mathrm{CaCO}_{3}$ within algal biofilms occurred. Deposition occurred as a direct result of photosynthesis which caused an increase in the $\mathrm{pH}$ of the medium. Once a critical $\mathrm{pH}$ had been reached, typically approximately $\mathrm{pH} 9.0$, precipitation began evidenced by a fall in the concentration of soluble calcium in the medium [17]. In other experiment, Synechococcus cyanobacteria, the eukaryotic Mychonastes sp., and Chlorella sp., were found to induce the precipitation of $\mathrm{CaCO}_{3}$ [18]. In all experiments the precipitation process developed in three stages: (1) a pH-drift period, (2) the actual precipitation reaction, and (3) an equilibration phase. The time intervals of the stages as well as the concentration changes found in the work were comparable to the results of other experimental studies on $\mathrm{CaCO}_{3}$ precipitation by algae as shown in table 3 and figure 3 [18].

Several types of microalgae also use urea hydrolysis mechanism to fulfil the needs of nitrogen. For example, Chorella sp utilizes urea as a nitrogen source; urea is hydrolysed by urease or urea amidolyase enzyme to produce ammonia and bicarbonate [19]. The activity of urease enzyme also can induce the precipitation of calcium carbonate $[11,12]$

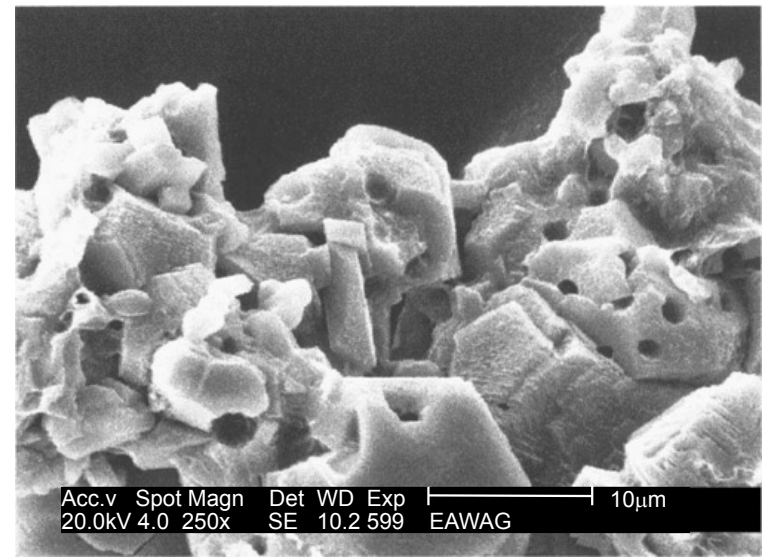

(a)

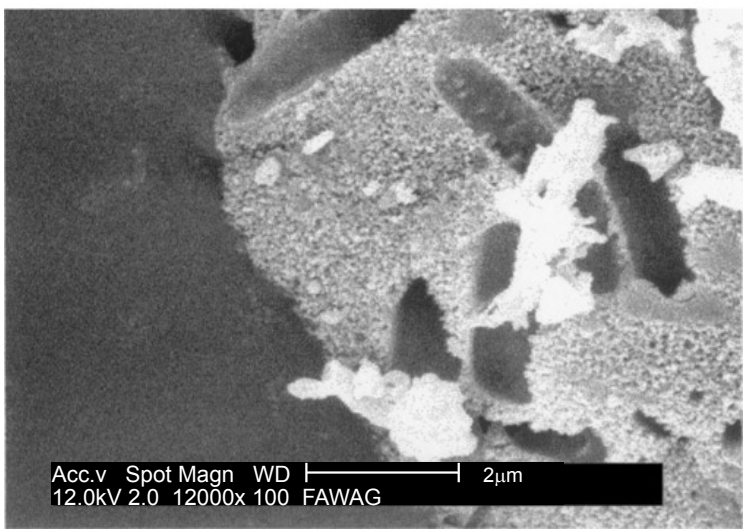

(b)

Figure 3: (a) SEM photograph of carbonate precipitates in presence of eukaryotic picoplankton, holes in the carbonate structure correspond to picoplankton cells and (b) picocyanobacteria [18]. 


\begin{tabular}{|c|c|c|c|}
\hline Type of microorganism & System & Chrystal type & Reference \\
\hline $\begin{array}{l}\text { Photosynthetic organism } \\
\text { Synechococcus GL24 } \\
\text { Chlorella }\end{array}$ & $\begin{array}{l}\text { Meromictic lake } \\
\text { Lurcene Lake }\end{array}$ & $\begin{array}{l}\left.\text { Calcite } \mathrm{CaCO}_{3}\right) \\
\text { Calcite }\left(\mathrm{CaCO}_{3}\right)\end{array}$ & $\begin{array}{l}{[21]} \\
{[18]}\end{array}$ \\
\hline $\begin{array}{l}\text { Sulfate reducing bacteria } \\
\text { Isolate } S R B L V \text { form } 6\end{array}$ & Anoxic hypersaline lagoon & Dolomite $\left(\mathrm{Ca}(\mathrm{Mg}) \mathrm{CO}_{3}\right)$ & - \\
\hline $\begin{array}{l}\text { Nitrogen cycle } \\
\text { Bacillus pasteurii } \\
\text { Bacillus cereus }\end{array}$ & $\begin{array}{l}\text { Urea degradation in synthetic medium } \\
\text { Ammonification and nitrate reduction }\end{array}$ & $\begin{array}{l}\text { Calcite }\left(\mathrm{CaCO}_{3}\right) \\
\text { Calcite }\left(\mathrm{CaCO}_{3}\right)\end{array}$ & $\begin{array}{l}{[10]} \\
{[1]}\end{array}$ \\
\hline
\end{tabular}

Table 2: Several species which already investigated as media in calcium carbonate precipitation [6].

\begin{tabular}{|c|c|c|c|c|c|c|}
\hline Experiment & Cell abundance $\left[10^{3}\right.$ cells.ml- $\left.{ }^{-1}\right]$ & Chlorophyll $\left[\mu \mathrm{g} . \mathrm{I}^{-1}\right]$ & pH drift time [h] & $\mathrm{pH}$ at Start of prec. & Length of prec. [h] & $\%$ of $\mathrm{Ca}^{2+}$ precipitation \\
\hline Mychonastes sp. (1) & 13.2 & 142 & 45 & 9.05 & 50 & 41 \\
\hline Mychonastes sp. (2) & 22.9 & 448 & 18 & 9.20 & 30 & 34 \\
\hline Chlorella sp. (1) & 6.85 & 222 & 25 & 9.00 & 10 & 26 \\
\hline Chlorella sp. (2) & 8.71 & 379 & 11 & 8.95 & 4 & 29 \\
\hline Synechococcus (1) & 33.4 & 130 & 40 & 8.95 & 40 & 13 \\
\hline Synechococcus (2) & 94.1 & 324 & 30 & 9.05 & 8 & 32 \\
\hline
\end{tabular}

Table 3: Precipitation experiments of $\mathrm{CaCO}_{3}$ induced by several types of algae [18].

There are some advantages of using microalgae as media for biocement production. Microalgae are type of renewable resources that easily cultivated rather than other type of microbe such as bacteria which already proved to be used in biocementation, so that its availability as raw material can be maintained properly. It's easy to grow especially in tropical area, where many non-agricultural landfills can be utilized as a raceway pond for microalgae cultivation. Tropical country also has a good temperature and water with high mineral contained which is very suitable for microalgae cultivation [15]. Another advantage is that the biocement production using microalgae can reduce the $\mathrm{CO}_{2}$ emission, which produced in conventional cement production $[5,3]$.

Based on table 3, the microalga is able to precipitate calcite very effectively within a couple days [18], while using bacteria such as Sporosarcina pasteurii is able to precipitate calcite under certain condition within 24 hours. But yet the exact data of experiment and literature still lack for the microalgae carbonate precipitation.

\section{Future Challenge}

Biocement is product innovation in material field that can be produce naturally using microorganism such as bacteria and microalgae. Microalgae have a great potential to be developed as media for biocement production through biocementation. Microalgae metabolism activity such as photosynthesize and hydrolysing urea can create the alkaline environment ( $\mathrm{pH}$ and DIC elevation), so that calcium carbonate precipitation occurs in the presence of calcium ion in the system.

On the other side, microalgae also part of renewable resource that is easily cultivated especially in tropical area, so that its availability as raw material can be maintain properly. Further basic research needs to be done, primary to the theme related to suitable type of microalgae, mechanism used in biocement production through biocementation, the kinetics of process, and also the optimum condition to produce good quality of biocement.

\section{References}

1. Castanier S, Levrel GLM, Perthuisot JP (1999) Ca-carbonates Precipitation and Limestone Genesis-The Microbiogeologist Point of View. Sedimentary Geolo 126: 9-23.

2. Muynck WD, Belie ND, Verstraete W (2010) Microbial Carbonate Precipitation in Construction Materials: A Review. Ecolo Eng 36: 118-136.

3. Khanafari A, Khams FN, Sepahy AA (2011) An Investigation of Biocement Production from Hard Water. Middle-East Journal of Scientific Research 7: 964-
971

4. Kucharski ES, Ruwisch RC, Whiffin V, Al-thawadi SM (2008) Microbial Biocementation. US Patent.

5. Jian C, Ivanov V (2009) Biocement - A New Sustainable and Energy Saving Material for Construction and Waste Treatment. Civil Eng Rese 7: 53-54.

6. Hammes F, Verstraete W (2002) Key Roles of pH and Calcium Metabolism in Microbial Carbonate Precipitation. Reviews in Enviro Sci \& Biotechnol 1: 3-7.

7. Whiffin Victoria S (2004) Microbial $\mathrm{CaCO}_{3}$ Precipitation for The Production of Biocement, PhD Thesis, School of Biological Science \& Biotechnology, Murdoch University.

8. Effendi H (2003) Study of water quality for water resources management and aquatic environment. ( $3^{\text {rd }}$ edition) Yogyakarta, Kanisius.

9. Belie ND (2010) Microorganisms Versus Stony Materials: A Love-Hate Relationship. Materials and Structure 43: 1191-1202.

10. Mc Connaughey TA, Water HA, Small AM (2000) Community and Environmental Influences on Reef Coral Calcification. Limnology and Oceanography 45 1667-1671.

11. Mobley HL, Hausinger RP (1989) Microbial Ureases: Significance, Regulation and Molecular Characterization. Microbial Reviews 53: 85-108.

12. Fisher SS, Galinat JK, Bang SS (1999) Microbial Precipitation of $\mathrm{CaCO}_{3}$. Soil Biology and Biochemistry 31: 1563-1571.

13. Santhosh KR, Ramakrishnan V, Sookie SB (2001) Remediation of Concrete using Microorganisms. Materials Journal 98: 3-9.

14. Giordano M, Beardall J, Raven JA (2005) $\mathrm{CO}_{2}$ Concentrating Mechanisms in Algae: Mechanisms, Enviromental Modulation, and Evolution. Annual Review Plant Biol 56: 99-131

15. Harun R, Singh M, Forde GM, Danquah MK (2010) Bioprocess Engineering of Microalgae to Produce a Variety of Consumer Products. Renewable and Sustainable Energy Reviews 14: 1037-1047.

16. Chen CY, Yeh KL, Aisyah R, Lee DJ, Chang JS (2011) Cultivation, Photobioreactor Design and Harvesting of Microalgae for Biodiesel Production: A Critical Review. Bioresour Technol 102: 71-81.

17. Heath CR, Leadbeater BSC, Callow ME (1995) Effects of inhibitors on calcium carbonate deposition mediated by freshwater algae. J Appl Phycol 7: 367-380.

18. Dittrich M, Kurz P, Wehrli B (2004) The Role of Autotrophic Picocyanobacteria in Calcite Precipitation in An Oligotrophic Lake. Geomicrobiol J 21: 45-53.

19. Perez-Garcia O, Escalante FM, De-Bashan LE, Bashan Y (2011) Heterotrophic Cultures of Microalgae: Metabolism and Potential Products. Water Res 45: 11-36

20. Bekheet IA, Syrett P (1977) Urea-degrading Enzymes in Algae. Brit Phycol J 12: $137-143$

21. Douglas S, Beveridge TJ (1998) Mineral Formation by Bacteria in Natural Microbial Communities. FEMS Microbiol Ecol 26: 79-88. 